\title{
How Different Forms of Corruption Affect the Economy of Bosnia and Herzegovina: A Research Project
}

\author{
Sabina Komić \& Nataša Tandir \\ International Burch University, Sarajevo, BOSNIA AND HERZEGOVINA \\ Faculty of Economics and Social Sciences
}

Received: 29 May 2020 • Accepted: 21 September 2020 • Published Online: 30 December 2020

\begin{abstract}
Corruption is globally viewed as dishonest and illegal behavioral activity that has negative influence on the overall economic and social environment. The aim of this research paper is to identify and examine effects of bribery, fraud, and favoritism on the economy of Bosnia and Herzegovina (B\&H). The research was conducted on the territory of B\&H including two hundred economic experts. The objective was to collect participants' opinions and experiences with corruption and its forms. Secondary data was extracted from books, journals, articles, and web pages. The findings show that majority of the participants encountered corruption but they did not report because they were mainly afraid of the illegal consequences they may face. The most widespread corruption form in $\mathrm{B} \& \mathrm{H}$ is bribery and the participants emphasized some of the effects of corruption on the economy such as uneven distribution of wealth, inefficient allocation of resources, lower growth rates, unfavorable business environment, demotivation of workers, slower process towards the European Union (EU) membership, etc. I concluded that as B\&H needs more time to become EU member, it loses the opportunity to establish fair and efficient trade, higher EU protection, larger budget, etc. Also, I realized that there is a high presence of corruption in $\mathrm{B} \& \mathrm{H}$ which does not decrease from year to year and appears in both public and private sector. This also destroys the legitimacy of the state and the quality of public services as well as the economic growth of $\mathrm{B} \& \mathrm{H}$.
\end{abstract}

Keywords: corruption, corruption forms, B\&H, economy.

\section{Introduction}

According to the previous researches corruption has been occurring in society ever since, but it has only been studied since 1995. It became a globalizing phenomenon that is rapidly expanding. Currently, the main focus of studies is to determine the negative effects of corruption on the countries and their economies as well as on the international institutions. Corruption and its forms have long been perceived as key barriers and obstacles for economic and social development of each country because these activities destroy national and international economic relations by reducing working ability and motivation, creating unfavorable business environment with unfair advantages, undermining the rule of law, causing political instability, etc.

It is evidenced that the countries with a high level of corruption do not prosper as fully as those countries with a low level of corruption because corrupted economies are not able to

(C) Authors. Terms and conditions of Creative Commons Attribution 4.0 International (CC BY 4.0) apply. Correspondence: Nataša Tandir (PhD), Faculty of Economics and Social Sciences, International Burch University, Francuske Revolucije bb, 71210 Ilidža, Sarajevo, BOSNIA AND HERZEGOVINA. E-mail: natasa.tandir@ibu.edu.ba. 
function properly due to the prevention of normal functioning of the natural laws of the economy and as a result the entire society suffers.

The research paper will focus on the effects of different forms of corruption (bribery, fraud, and favoritism) on the overall economy of B\&H. There are two main objectives of this research paper. The first objective is to measure the awareness of the selected participants regarding the presence of corruption. The next objective is to examine the opinions and experiences of the participants regarding the effects of mentioned forms of corruption on the economy of B\&H. For the research purposes, I will use primary and secondary data. Primary data will be collected through the survey that will be distributed to two hundred economic experts. The research will be conducted on the field of B\&H. The data collected from the survey will be passed to Microsoft Excel and SPSS where I will conduct many statistical tests. Secondary data will be derived from different scientific sources.

There are few reasons why I chose to research this topic. One of them is that I wanted to learn more things about the causes and forms of corruption because in many cases the majority of the Europeans associate B\&H with this term. Many Bosnian people also heard about corruption and its forms because they are mainly involved in these activities (directly or indirectly), but just small percent of people is aware of the negative influence over the economy of B\&H.

This research proposal will be drafted in a standardized form with eight main parts: Abstract, Introduction, Literature review, Research questions and model, Methodology, Data and findings, Conclusion, and References. In the "Literature review" part the main terms regarding corruption, bribery, fraud, favoritism, and economy of B\&H are explained. The fourth part, "Research questions and model", represents a model with relations as well as the hypotheses of the proposal. The next section, "Methodology", explains data collection and methods that are used for a statistical analysis in order to provide concrete and significant results of the research paper. All these results are listed in the next part which is called "Data and findings". The seventh part of this research proposal "Conclusion" explains all the findings and benefits of the research. In the "References” part, I listed all bibliography I used for my research proposal.

\section{Literature review}

For the purpose of this study, great number of published papers was used and based on this, the research model was proposed. The review is going to provide basic insights in up to date information regarding to corruption and its forms, the effects of these forms, as well as economic situation of Bosnia and Herzegovina.

\subsection{Definitions and concept evaluation}

\subsubsection{Corruption}

Brooks, Walsh, Lewis \& Kim (2013) state that corruption is variously interpreted term due to the many scientific fields e.g. economy, policy, and law that examine this term from different context and perspective. As a result, there is no ultimate definition of the term, it is rather viewed as a complex phenomenon that has plenty causes and effects. Corruption is seen as an emotionally loaded idea that guides to some general judgement.

They also argue that corrupt behavior is not recent phenomenon, but the level of this misconducts increased in the last century due to the: increased international trade, differences in economic development between the countries, political and marketable monopolization, lack of leadership, cultural diversification, lack of education, lack of international laws reforms, materialistic desires, and similar. According to Milovanović (2001), corruption derived from the 
Latin word "corruptio" which means bad and evil behavior. He also claimed that the rules of the society are crucial when defining the corrupt behavior, but they are still not specific enough to provide us with the concrete definition. On the other side, Sumah (2017) indicates that corruption derived from the Latin word "corruptus" that represents the abuse of a trusted and powerful position (e.g., judicial or executive) with an aim to obtain certain kind of illegal benefit.

According to the Transparency International (2018), the national corruption level did not change since 1997. Unfortunately, in the following years, the annual corruption index of the countries located all around the world may even increase due to the democracy crisis. The Chair of Transparency International, Delia Ferreira Rubio said: "Corruption is much more likely to flourish where democratic foundations are weak and, as we have seen in many countries, where undemocratic and populist politicians can use it to their advantage". Aside from the United States, Australia, Canada, and some European countries, the rest of the world is beset by corrupt behavior. Africa and Asia are the most corrupt continents. European countries are dominating within the very clean countries in terms of corrupt behavior in 2018 . B\&H is ranked on the $89^{\text {th }}$ place and since 2015, the score of B\&H did not change, there was just a small increase in 2016 when the score was 39. The neighboring countries of $\mathrm{B} \& \mathrm{H}$ had better rank, i.e. Croatia is ranked on the $60^{\text {th }}$ place, Montenegro on the $67^{\text {th }}$ place, and Serbia on the $87^{\text {th }}$ place.

Berg (2001) states that there are two ways to measure a corrupt behavior and those are objective and subjective measure. An objective measure is based on the data that can be verified and proved e.g. audit reports of corrupt behavior. A subjective measure is based on the surveys where participants are asked about their perception and experiences with corrupt behavior. Kaufmann, Hellman, Jones \& Schankermanm (1999) argue that the only way to overcome the limitations of these two measures is to use the aggregate indicators which combine different forms of subjective and objective measures. The aggregate indicators became popular since 1990 in order to provide more relevant corrupt behavior assessment. There are many advantages from the usage of these indicators and those are: wider country coverage, reduction of errors and biases, and so on. Other names for these indicators are "second-generation measures" and "composite indicators".

Pasculli and Ryder (2019) indicate that corruption became a global phenomenon and global crime that rapidly expands all over the world in a way that corrupt practices available in one country can be expanded to more countries - geographical extension and financial magnitude. They also state that countries with a high level of corruption do not prosper as fully as those countries with a low level of corruption. The proof for this is that the average income in countries with a high level of corruption is about a third of that of countries with a low level of corruption, which means that corruption is perceived as an obstacle for economic and social development. Corruption causes inefficient allocation of resources, uneven distribution of wealth, presence of shadow businesses, poor public services, lower quality of products, etc.

Alt and Lassen (2003) state that the causes of corrupt behavior can be divided into six different categories: economic, geographical, cultural, demographic, political, and bureaucratic (also called judicial) category. All of these categories represent different reasons that can cause a corrupt behavior, but the majority of these reasons are correlated or they influence one another. Also, these reasons vary from study to study, so there is no specific classification that is acceptable and used by all researchers.

Dimant and Schulte (2016) conducted a research that included insights from economics, criminology, and psychology, a corruption became a focal point on majority of political agendas. Today's society puts a pressure on governing bodies to fight against the spread of corrupt behavior because the presence of this behavior has the negative influence on the overall environment. A corrupt behavior is a threat to the economic growth of developed and developing countries, on foreign direct investments (FDI), productivity of the firms. Such behavior increases 
the inequality within society, induces immigration of highly skilled and educated people, as well as effects social norms and values.

\subsubsection{Forms of corruption}

Deininger and Mpuga (2005) identified five main forms of corruption: bribery, fraud, favoritism, extortion, and embezzlement. Bribery is the most present form of corruption and it is defined as "the payment of money or other goods in kind that is provided or taken within a corrupt relationship". A bribe can be paid in certain amount of money, fixed percentage of contract, or in some other financial forms. Majority of the bribes are paid to the public officials that are in positions to make the contracts for the state so they have a power to distribute the favors and benefits to a person who gave bribe. Lowenstein (2005) states that the bribery can become a dominant act of the corruption and this case is known as the "black core". There are some situations when the black core is not accorded as harmful act because there are no identified victims which are directly affected with it which is not the case with theft, murder, and so on. The corrupt and bribery acts can have an impact on the law, taxes, market and by this way disperse the negative effect on more victims with the lack of visibility. Oyani and Frederick (2019) argue that bribery is one of the most dangerous form of corruption that hurts the society especially the poor communities as well as it hampers the development of these communities. Bribery also undermines the economic growth and represents an obstacle to poverty alleviation and good governance. Sometimes, bribery can worsen conflict and insecurity in the country by destroying national and international economic relations. When there is a high presence of bribery in a country, the whole economic development of that country is slowed down due to demotivation of workers, unfavorable business environment encouraged by unfair advantages and anticompetitive practices, lower quality of public services and officials, and so on. Bribery also causes inefficient allocation of resources, lower growth rates, reduced production levels and business competitiveness.

According to the Transparency International (2018) and the report called "People and corruption" every fourth participant said that it was engaged in bribery while accessing some public services such as medical care, school, religious centers, court, and so on. The worldwide participants perceive the European Union as the region with the lowest bribe activity. The most bribery activity is recorded in Yemen (77\%), India (69\%), Liberia (69\%), Vietnam (65\%), and Mexico (51\%). On the other side, the least bribery is recorded in the United Kingdom (0\%), Japan (o\%), Botswana (1\%), Sweden (1\%), Portugal (2\%), and France (2\%). It is perceived by the respondents that $\mathrm{B} \& \mathrm{H}$ had a bribery rate of $27 \%$, Serbia $22 \%$, and Croatia $10 \%$.

Brooks, et al. (2013) state that fraud represents situation when something valuable is obtained or certain obligation avoided through deception. Since 2oth century, fraud is constantly spreading and it is considered as serious criminal offence. Fraud embraces different kinds of conduct, including individuals who make false claims to corporations. Every fraud involves cheating, dishonesty, and swindling. When it comes to the factors that cause fraud, they can be presented in so called "fraud triangle" that includes rationalization, opportunity, and pressure. There are some other causes besides fraud triangle such as high personal debt, living beyond income, outrages gambling, desire for progression, and so on.

Moncarz, Moncarz, Cabello and Moncarz (2006) argue that the most present fraud is related to finance and accounting. This kind of fraud may negatively affect the true profitability of the fraudulent company, or even cause a collapse of that company as was the case with Enron, but it can also affect the whole financial markets, industry profits, investors, products surplus, and the overall social welfare. 
According to Loewe, Blume, Schonleber, Seibert, Speer and Voss (2007) favoritism may have two different meanings. The first meaning is related to the favor of one person or group over others, while the second meaning implies preferential treatment of those to whom one has some personal connection such as relatives, friends, race, ethnic group, party, origin, clan, and so on. This form of corruption can arise in interactions between public sector officials and businesspeople, as well as through the interactions between private sector agents. The most present form of favoritism is nepotism, when person with power nominate its family members (e.g. wife, husband, children, nephew) to public positions e.g. certain political position. Further, majority of these family members will move to private businesses and by this way the public power will be transferred to private wealth. It is important to highlight that favoritism is not just illegal, it is also harmful for the whole system because in majority of the situations employed family members do not possess required skills, knowledge, abilities, and qualifications for those positions which has a negative effect on everyone except those families that have financial advantages. By this way, favoritism can lead to unfairness and inefficiencies in the state-business relations. Also, favoritism may impact the legislation and policy-making process by lobbying regulations and distorting competition which increases the costs and risks to the investors.

Brooks et al. (2013) argue that extortion represent extracting money and other valuable resources by using violence, coercion, or force, while embezzlement is the situation when public officials steal public resources (e.g. misuse of public funds) or when private sector employees thieve their employers. Extortion creates unsecured and vulnerable atmosphere where power holders intimidate and harass other people without power. The only persons that are exempted from this harassment are those who pay required amount of money for the protection. This can be seen within organized crimes, but also there are many registered situations when public officials are asking for valuable resources from private companies. In a case of embezzlement, many states recorded situations when person used its political power as a way to enter and expand its private business. Some power holders are even controlling the media to work in his/her best interest. In the countries with high embezzlement rate, the whole population is deprived. These two forms of corruption are quite non-present in comparison to other three forms.

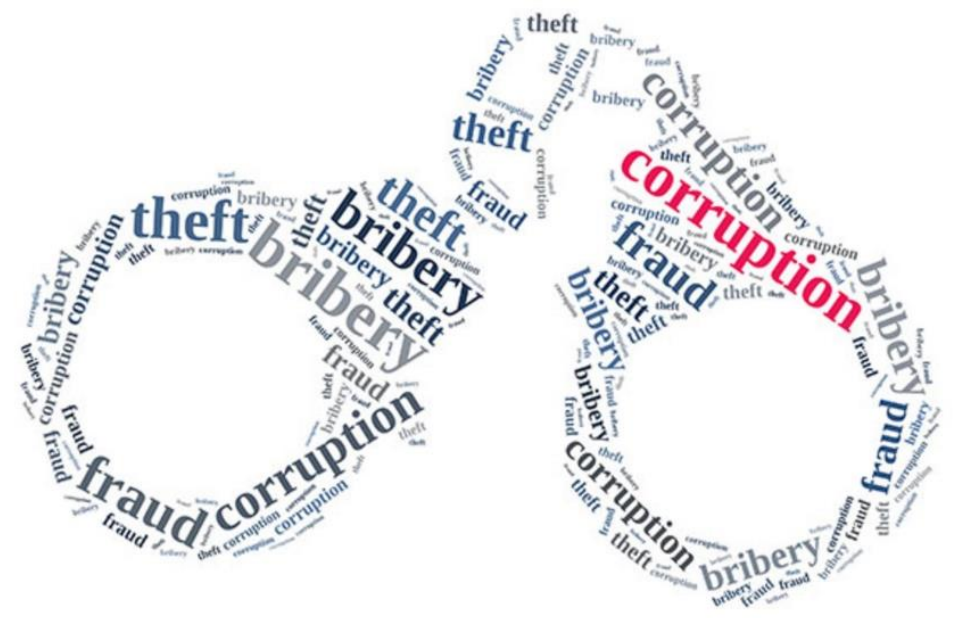

Figure 1. Forms of corruption

\subsection{Economy of Bosnia and Herzegovina}

In addition to the mentioned effects of these corruption forms, they also have negative effect on the B\&H application process towards EU membership. B\&H submitted its EU 
membership application to the European Council of the EU on 15 February 2016. Since that year, the European Commission annually assess the applicant's ability to meet Copenhagen criteria and then adopts its opinion known as "Commission Opinion on Bosnia and Herzegovina's application for membership of the European Union". According to the Current Opinion that dates from 29 May 2019 B\&H does not still fulfill the all Copenhagen criteria and in order to become the EU member, $\mathrm{B} \& \mathrm{H}$ has to fulfill it. One of the highest problems for $\mathrm{B} \& \mathrm{H}$ is related to the corruption level in B\&H and organized crime. The country faces with these problems due to the lack of coordination and cooperation between institutions, as well as not harmonized legislation across $\mathrm{B} \& \mathrm{H}$.

The country has the gaps in legal and institutional framework that govern prevention of corruption, while the law agencies are vulnerable due to the political interference. Also, the country's sanctions for corrupt activities are not so effective, which induce higher corruption level. The everyday life of Bosnian citizens is affected by the corruption because it is widespread at all government levels that influences education, health, employment, and other systems. In order to become the EU member, the country has to fight against these problems European Commission (2019).

\section{Hypotheses and research model}

This research includes bribery, fraud, and favoritism as the variables that are influencing the economy of B\&H. These variables are chosen based on the previous research studies where they are recognized as the barriers of economic growth. According to the European Commission's report these variables are also recognized as the obstacles to join the EU.

The research will have three research questions:

B\&H?

Research question 1: How presence of bribery affects the economy of

Ho1: There is no effect of presence of bribery on the economy of B\&H.

H11: There are possible effects of presence of bribery on the economy of B\&H.

Research question 2: How presence of fraud affects the economy of B\&H?

Ho2: There is no effect of presence of fraud on the economy of $\mathrm{B} \& \mathrm{H}$.

H12: There are possible effects of presence of fraud on the economy of $\mathrm{B} \& \mathrm{H}$.

B\&H?

Research question 3: How presence of favoritism affects the economy of

Ho3: There is no effect of presence of favoritism on the economy of B\&H.

H13: There are possible effects of presence of favoritism on the economy of B\&H. 


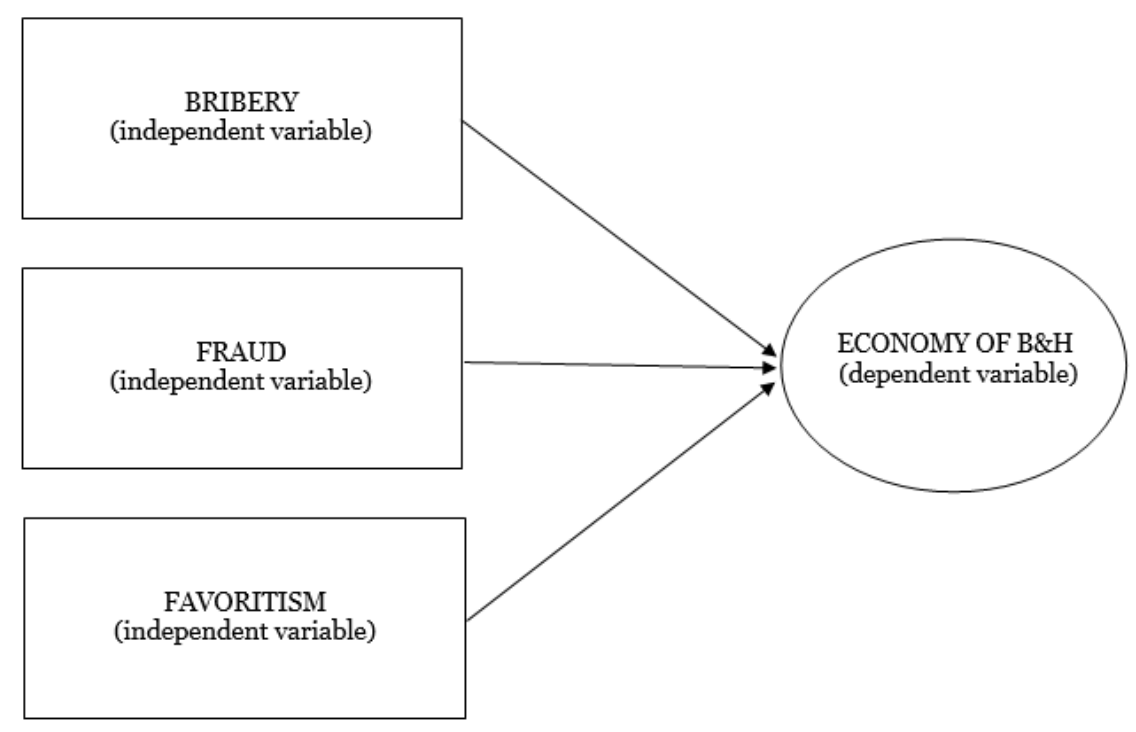

Figure 2. General scheme of the research

\section{Methodology}

The research will be conducted on the field of B\&H including two hundred economic experts that will answer on the delivered survey questions. This means that I will use nonprobability sampling where I will focus on special population through the data collection process. The survey will be created using Google Forms with an aim to target participants' opinions, experiences, and knowledge regarding the effects of corruption on the economy of $\mathrm{B} \& \mathrm{H}$. The data collected from the survey will be primary data and this data will be passed to Microsoft Excel in order to decode file for the SPSS analyses. These analyses will be conducted using different statistical tests: Descriptive Statistics, Comparing Means (one-sample t-test), ANOVA, Chi-square test of independence, Correlation analysis (bivariate and partial correlation), and Multiple regression.

The process of data collection will have two aims. The first aim will be to measure the awareness of the selected participants regarding the presence of corruption and its forms in $\mathrm{B} \& \mathrm{H}$ e.g. their encountering with corruption, identification of places where the participants encounter corruption, effects of corrupt activities on their everyday life especially on their job, list effective methods to fight against corruption, and so on. The second aim of the survey will be to examine the opinions and experiences of the participants regarding the effects of these three forms of corruption on economy of $\mathrm{B} \& \mathrm{H}$ and the application process of $\mathrm{B} \& \mathrm{H}$ for the EU membership. It is important to highlight that while collecting the data, the survey will provide certain information that can help the participants in the future to effectively fight against corruption. Even though that the survey will be anonymous and confidential, the whole process of data collection can be limited due to the participants' disinterest to fill the survey because they think that they will face certain consequences. Secondary data will be derived from different scientific sources such as books, journals, articles, web pages and it will be used for writing the literature review.

\section{Expected results}

It is projected that the data analyses will prove that all mentioned forms of corruption (bribery, fraud, and favoritism) have negative effect on the Bosnian economy and EU membership process of $\mathrm{B} \& \mathrm{H}$. It is also forecasted that the majority of the participants say that they encounter 
some corruption form in the past five years either being directly or indirectly involved in such unethical activity. As the main causes of corruption, it is projected that the participants identify ineffective prosecution and legal framework in $\mathrm{B} \& \mathrm{H}$, low income level, lack of knowledge, etc. Also, it is forecasted that the majority of the participants say that corruption level increases from year to year. Some of the effects of corruption presence that participants may emphasize are slower economic development, uneven distribution of wealth, inefficient and unequal allocation of resources, unfavorable business environment, demotivation and disrespect of workers, and slower process towards the EU membership.

\section{Conclusion}

The aim of the study will be to determine the effects of selected corruption forms on the economy of B\&H. Data will be collected from the primary and secondary sources. The primary data will be collected through the survey. The sample will be comprised from two hundred economic experts located in B\&H. Data will be processed and analyzed with usage of Microsoft Excel and SPSS. The secondary data will be collected from the scientific and professional literature. It is expected that the findings will show that majority of the participants encountered some corruption form but they did not report such activity.

Also, it is projected that the selected participants are afraid to report some corrupt activities due to the illegal consequences they may face. Majority of the participants will also think that they do not have power over corruption in B\&H so they accepted "the reality" in which they live so they are forced to even work in corrupt communities in $\mathrm{B} \& \mathrm{H}$, or they are leaving $\mathrm{B} \& \mathrm{H}$ to find job in some foreign countries. As in the previously conducted researches, it is expected that participants say that the level of corruption increased in comparison with previous years due to the insufficient fight against corruption from the side of public institutions in $\mathrm{B} \& \mathrm{H}$ and ineffective prosecution and legal frameworks.

Findings will probably show that participants are aware of the negative effects of every corruption form and that they realize that the presence of corrupt activities slower economic growth, distributes wealth unevenly, allocates resources ineffectively, creates unfavorable business environment, leads companies to collapses, demotivates workers, etc. The participants also may express their understanding of the strict EU policies and regulations that are against every corruption form which means that $\mathrm{B} \& \mathrm{H}$ cannot enter the EU until corrupt activities are reduced to minimum level. It is also projected that the participants will show that they are familiar with the benefits that EU membership can bring to $\mathrm{B} \& \mathrm{H}$ in order to improve the overall economic, political, and social situation in B\&H. Therefore, we can conclude that there is a high presence of mentioned corruption forms in B\&H which does not decrease from year to year and appears in both public and private sector.

The presence of these unethical activities has negative impact on the overall economic and social environment in B\&H which slows down the economic development as well as the process of $\mathrm{B} \& \mathrm{H}$ to join the $\mathrm{EU}$. As $\mathrm{B} \& \mathrm{H}$ needs more time to become EU member, it loses the opportunity to have fair and efficient trade based on common goods/services regulations, the same external and no internal tariffs and quotas, regulated prices, larger customer base, free movements (goods, services, persons, and capital), EU protection, budget, etc.

This research paper will bring benefits to the several key groups. The study may help people and organizations to better understand the negative effects of corruption on the overall economic environment in $\mathrm{B} \& \mathrm{H}$, but they will also realize that there are some things that they can do to reduce this unethical activity e.g. report every activity that has corrupt elements. In order to fight against these activities, people will be able to get familiar with all forms and causes of corruption. People interested in this research will be able to understand the application process to 
join the EU and to realize in which stage B\&H is now. Also, they will expand their knowledge regarding the benefits of the EU membership.

\section{Acknowledgements}

This research did not receive any specific grant from funding agencies in the public commercial, or not-for-profit sectors.

The authors declare no competing interests.

\section{References}

Alt, J. E., \& Lassen, D. D. (2003). The political economy of institutions and corruption in American states. Journal of Theoretical Politics, 15(3), 341-365. https://doi.org/10.2139/ssrn.353880

Berg, E. (2001). How should corruption be measured? MSc. economics extended essay. London School of Economics and Political Science.

Brooks, G., Walsh, D., Lewis, C. et al. (2013). Preventing corruption: Investigation, enforcement and governance. London: Palgrave Macmillan.

Deininger, K. \& Mpuga, P. (2005). Does greater accountability improve the quality of public service delivery? Evidence from Uganda. World development, 33(1), 171-191. https://doi.org/10.1016/j.worlddev.2004.09.002

Dimant, E., \& Schulte, T. (2016). The nature of corruption: An interdisciplinary perspective. German Law Journal, 17(1), 53-72. https://doi.org/10.1017/S2071832200019684

European Commission (2019). Retrieved from: https://ec.europa.eu/neighbourhoodenlargement/sites/near/files/20190529-bosnia-and-herzegovina-analytical-report.pdf

Kaufmann, D., Kraay, A., \& Zoido, P. (1999). Governance matters. World Bank policy research working paper, (2196).

Loewe, M., Blume, J., Schönleber, V., Seibert, S., Speer, J., \& Voss, C. (2007). The impact of favouritism on the business climate: A study on wasta in Jordan. https://doi.org/10.2139/ssrn.2218821

Lowenstein, D. H. (2005). Political Bribery and the Intermediate Theory of Politics, UCLA Law Review, 32, 784-851.

Milovanović, M. (2002). Endogenous corruption in privatized companies. Unpublished manuscript.

Moncarz, E. S., Moncarz, R., Cabello, A., \& Moncarz, B. (2006). The rise and collapse of Enron: Financial innovation, errors and lessons. Contaduría y Administración, (218), 17-37. https://doi.org/10.22201/fca.24488410e.2006.579

Oyani, M. N., \& Frederick, A. J. (2019). Impact of bribery on social development of Afghanistan's economy. International Journal of Multidisciplinary Research and Development, 6(6), 144-152.

Pasculli, L., \& Ryder, N. (Eds). (2019). Corruption in the global era: Causes, sources and forms of manifestation. New York: Routledge.

Sumah, S. (2018). Trade and global market: Corruption, causes and consequences. IntechOpen. https://doi.org/10.5772/intechopen.72953

Transparency International (2018). Retrieved from https://www.transparency.org/whatwedo/publication/corruption_perceptions_index 208. 
S. Komić \& N. Tandir - How Different Forms of Corruption Affect the Economy of ...

C O A $\mathrm{s}$ 